\title{
Analysis on The Effect of Compensation, Discipline and Motivation Toward Performance of Employees of Mandiri Utama Sejahtera Corporation
}

\author{
Rahmi Hermawati \\ Universitas Pamulang \\ Email: rahmi.hermawati@gmail.com
}

(Received: February 11-2020; revised: June 16-2020; published: June 30-2020)

\begin{abstract}
This study aims in examining the problem of employee performance that has decreased. The main objective of this research is to find out the phenomenon and to obtain empirical evidence and conclusions about the effect of compensation, discipline and motivation toward the performance of employees of Mandiri Utama Sejahtera corporation. This research uses a quantitative design method, explanatory research, by testing the survey technique hypothesis, the questionnaire uses a Likert scale of 4 , using a saturated sample, which means using the entire population of 96 employees with headquarters and 5 warehouses in several areas. The results of the study were processed using data analysis techniques: (1) validity and reliability tests; (2) classic assumption test (normality, homogeneity, heteroscedasticity and multicollinearity test); (3) coefficient of determination (R2); (4) simple and multiple regression models; (5) hypothesis testing with partial test ( $t$ test) and simultaneous ( $F$ test). Based on the results of the study it was found that the $\mathrm{F}$ test showed a very significant effect on the compensation variable (X1), the discipline variable (X2), and the motivation variable (X3) together on the Performance variable (Y). This is evidenced by the calculated $F_{\text {count }}(49,460)>F_{\text {table }}(2.70)$ and the significance is less than $5 \%(0,000$ $<0.05)$. $\mathrm{R}$ value (correlation) is 0.786 and $\mathrm{R}$ Square value (determination) is 0.617 , indicating that the variable $\mathrm{Y}$ (employee performance) is influenced by variable X1 (compensation), variable X2 (discipline), and variable X3 (motivation) together, of $61.70 \%$ and the remaining $38.30 \%$ is influenced by other factors not examined. So the conclusion of the research results shows that there is a positive and significant influence of compensation, discipline and motivation on the performance of employees of Mandiri Utama Sejahtera corporation
\end{abstract}

Keywords: Compensation; discipline; motivation; performance.

\section{INTRODUCTION}

Human resource is a driving factor in the implementation of corporation activity, because human resource has the creativity and the expertise to get companies to their goals (Bircan \& Gençler, 2015; Nicolau \& Foris, 2018; Vardarlıer, 2016). In addition to competition between companies, human resource is also one that will be facing competition within the MEA. One of factors that causes human resource to compete and can help company in achieving their goals is the good performance of each employee (Sunarsi, 2014, 2018a, 2018b; Sunarsi \& Yuliani, 2019). Stolovich and keeps inside rivai,et al. (2011:14) points out that "performance is a set of 
100 Jurnal Ilmiah Ilmu Administrasi Publik: Jurnal Pemikiran dan Penelitian Administrasi Publik Volume 10 Number 1, January- june 2020. Page 99-112

results achieved and referring to the achievement action and executing of a work which is wanted."

Convenience of working supported by compensation being given by company (Kim \& Jang, 2020; Kusuma \& Ardana, 2014). Its Compensation is essential for employees to stimulate employees to do work like organizational expectations.they will work more effectively, efficiently, in charge of high discipline (S. Doyle, 2019; Levine \& Modica, 2016; Waris, 2015). "According to (Sastrohadiwiryo, 2010), discipline is a respect attitude, appreciating, and obeying to the exist regulations, both written and unwritten, and being able to run the regulations and not to deny to receive the sanctions when they violated the duties and authority given them.

With good compensation, it will indirectly motivate them to carry out their duties and responsibilities to achieve the company's goals effectively and efficiently (Bebchuk \& Fried, 2012; Core et al., 1999; Gerhart, 2008). High motivation certainly encourages employees to want to rear companies just as their companies do (Niswaty et al., 2017; Saggaf et al., 2018). If sense of belonging has already existed, then an employee will be responsible for their job. This high responsibility and sense of belonging will trigger them to work in discipline. They don't want companies to go bankrupt or to collapse, because of their indiscipline and lack of serious in working. According to (Brown et al., 2015; Freitas \& Duarte, 2017; Sujatha \& Krishnaveni, 2018), high-performance work system is a framework of human resources that facilitates employee engagement, improved skills, and motivation.

According to Act, it was explained that wages are a worker's right to be given by employers in recompense or in return for contributions to companies. The wages they received must be in accordance with the minimum wage that being determined by the local government (article 90 section 1 of the constitution no.13/ 2003). Low compensation (incompatible with the regional minimum wage), job discipline, and lack of motivation in work will result in the goals and target having been determined by company not to be achieved well. The company's target set cannot be achieved because there are those barriers.

In connection with regulation having been determined by government above related by compensation, Researchers are seeing a phenomena in Mandiri Utama Sejahtera corporation where many employee got salary under UMK (minimum wage of the regency,Appropriate the accompanying data: 
Table 1.

Structure of Employee salary

\begin{tabular}{|c|c|c|c|c|c|c|c|}
\hline \multirow[b]{2}{*}{ Level } & \multicolumn{7}{|c|}{ Salary Range Data of PT. MUS 2019} \\
\hline & Area & UMK & Lowest & Highest & Gap & $\begin{array}{c}\text { Total } \\
\text { Employees }\end{array}$ & $\begin{array}{c}\% \text { Under } \\
\text { the UMR }\end{array}$ \\
\hline \multirow{6}{*}{ Operator } & Tangsel & 3.841 .368 & 1.750 .000 & - & 2.091 .368 & 1 & \multirow{6}{*}{$73 \%$} \\
\hline & Bekasi & 4.229.756 & 1.500 .000 & 1.600 .000 & 2.629 .756 & 18 & \\
\hline & Tasik & 2.086 .529 & 1.700 .000 & 1.800 .000 & 286.529 & 4 & \\
\hline & Nganjuk & 1.801 .406 & 1.400 .000 & 1.603 .000 & 401.406 & 21 & \\
\hline & Madura & 1.801 .406 & - & 1.820 .000 & - & 16 & \\
\hline & Magelang & 1.882 .000 & 1.400 .000 & 1.550 .000 & 482.000 & 3 & \\
\hline \multirow{6}{*}{ Staff } & Tangsel & 3.841 .368 & 2.000 .000 & 3.900 .000 & 1.841 .368 & 6 & \multirow{6}{*}{$79 \%$} \\
\hline & Bekasi & 4.229 .756 & 2.635 .000 & 3.600 .000 & 1.594 .756 & 4 & \\
\hline & Tasik & 2.086 .529 & - & 1.700 .000 & 386.529 & 1 & \\
\hline & Nganjuk & 1.801 .406 & 2.005 .000 & 2.055 .000 & - & 2 & \\
\hline & Madura & 1.801 .406 & - & 1.860 .000 & - & 1 & \\
\hline & Magelang & 1.882 .000 & - & 2.100 .000 & - & 1 & \\
\hline \multirow{6}{*}{ Supervisor } & Tangsel & 3.841 .368 & 3.600 .000 & 4.042 .000 & - & 3 & \multirow{6}{*}{$25 \%$} \\
\hline & Bekasi & 4.229 .756 & 1.850 .000 & 4.380 .000 & 2.379 .756 & 4 & \\
\hline & Tasik & 2.086 .529 & - & 3.350 .000 & - & 1 & \\
\hline & Nganjuk & 1.801 .406 & 2.599 .200 & 3.055 .000 & - & 3 & \\
\hline & Madura & 1.801 .406 & - & 3.755 .000 & - & 3 & \\
\hline & Magelang & 1.882 .000 & - & 2.900 .000 & - & 1 & \\
\hline Manager & - & - & 4.600 .000 & 5.070 .000 & - & 3 & $0 \%$ \\
\hline \multicolumn{7}{|r|}{96} & $\mathbf{4 4 \%}$ \\
\hline
\end{tabular}

Source of data: data of salary structure of HRD in Mandiri Utama Sejahtera Corporation (2019)

The table 1 above shows that there is gap high to a staff level of $79 \%$, an operator level of $73 \%$ and a supervisor of $25 \%$, which means that a $44 \%$ employee salary is still below UMK(minimum wage of the regency. Another phenomenon that was found was a drop in attendance and discipline. Being Enclosed are data on the attendance and employee discipline tables.

Table 2.

Absence of Employee

\begin{tabular}{|r|r|r|r|r|r|r|r|r|}
\hline No & Year & Present=P & Sick= S & Absent = A & $\begin{array}{l}\text { Business } \\
\text { Trip = BT }\end{array}$ & Other = 0 & $\begin{array}{c}\text { In } \\
\text { Efficiency }\end{array}$ & $\begin{array}{l}\text { Target of } \\
\text { attendance }\end{array}$ \\
\hline 1 & 2016 & $72 \%$ & $1 \%$ & $5 \%$ & $5 \%$ & $1 \%$ & $15 \%$ & $95 \%$ \\
\hline 2 & 2017 & $71 \%$ & $3 \%$ & $4 \%$ & $2 \%$ & $2 \%$ & $18 \%$ & $95 \%$ \\
\hline 3 & 2018 & $69 \%$ & $7 \%$ & $3 \%$ & $6 \%$ & $3 \%$ & $12 \%$ & $95 \%$ \\
\hline
\end{tabular}


102 Jurnal Ilmiah Ilmu Administrasi Publik: Jurnal Pemikiran dan Penelitian Administrasi Publik Volume 10 Number 1, January- june 2020. Page 99-112

Data source: HRD data on employee absence in 2016, 2017 and 2018

The aforementioned table 2 shows a drop in employee attendance from 2016 by 72 percent, 2017 by $71 \%$ and 2018 to $69 \%$, which means that it is still well below the company's target for 95 percent.

Table 3.

Employee Lateness

\begin{tabular}{|r|c|r|r|r|r|r|r|r|}
\hline No & Month & $<09.00$ & $\begin{array}{c}09.01- \\
09.15\end{array}$ & $\begin{array}{c}09.16- \\
10.00\end{array}$ & $\begin{array}{c}10.01- \\
11.00\end{array}$ & \multicolumn{1}{c|}{$>11.00$} & $\begin{array}{c}\text { In } \\
\text { discipline }\end{array}$ & \multicolumn{1}{c|}{$\begin{array}{l}\text { Delay } \\
\text { Target }\end{array}$} \\
\hline 1 & 2016 & $75 \%$ & $10 \%$ & $9 \%$ & $3 \%$ & $3 \%$ & $25 \%$ & $5 \%$ \\
\hline 2 & 2017 & $89 \%$ & $2 \%$ & $3 \%$ & $1 \%$ & $5 \%$ & $11 \%$ & $5 \%$ \\
\hline 3 & 2018 & $80 \%$ & $7 \%$ & $5 \%$ & $3 \%$ & $5 \%$ & $20 \%$ & $5 \%$ \\
\hline
\end{tabular}

Data source: HRD data of employee lateness in 2016, 2017 and 2018

Table 3 shows that there's a lateness rate below the company's target, which is $5 \%$. It shows a lack of motivation in work. The drop of attendance rate was also due to their failure to heed the warning letters, because the company tolerated so much. No strict sanctions were imposed on employees who came late and didn't even show up for work. The rules that have been set don't work because of any number of reasons. Employees don't have the motivation to make a change such as in making a good report, performing the work standard by standard operational procedure.

Less eager to make improvements in the work, just following what's been in operation for a long time. Based on the above description, it shows how important the role of compensation factor, discipline, and motivation in increasing the performance of employees.this is also seen at the performance of Mandiri Utama Sejahtera corporation,to be seen on chart below:

Table.4.

Actual sales 2017 and 2018

\begin{tabular}{|c|c|c|c|c|c|c|c|}
\hline No & Description & 2017 & $\%$ & 2018 & $\%$ & Ups and down & $\%$ Ups and down \\
\hline \multirow{5}{*}{$\begin{array}{l}1 \\
\\
\\
\\
\end{array}$} & Sales & 19.315.147.142 & & 22.256 .704 .000 & & 2.941 .556 .858 & $13 \%$ \\
\hline & - Container & 184 & & 174 & & (10) & $-6 \%$ \\
\hline & - Koli & 49.768 & & 46.486 & & (3.282) & $-7 \%$ \\
\hline & - Container PUN & - & & 46 & & 46 & $100 \%$ \\
\hline & - Koli PUN & - & & 11.741 & & 11.741 & $100 \%$ \\
\hline \multirow{3}{*}{2} & COGS & 15.940 .770 .949 & $82,5 \%$ & 19.173.099.445 & $86,1 \%$ & 3.232 .328 .496 & $17 \%$ \\
\hline & - Direct Cost & 12.846 .018 .827 & $66,5 \%$ & 15.857 .894 .266 & $71,2 \%$ & 3.011 .875 .439 & $19 \%$ \\
\hline & - Indirect Cost & 3.094 .752 .122 & $16,0 \%$ & 3.315 .205 .179 & $14,9 \%$ & 220.453 .057 & $7 \%$ \\
\hline 3 & Gross Profit & 3.374.376.193 & $17,5 \%$ & 3.083 .604 .555 & $13,9 \%$ & $(290.771 .638)$ & $-9 \%$ \\
\hline \multirow{6}{*}{$\begin{array}{l}4 \\
\\
4\end{array}$} & GA & 2.552 .577 .826 & $13,2 \%$ & 1.902 .623 .128 & $8,5 \%$ & (649.954.698) & $-34 \%$ \\
\hline & - Salary + Allowance & 1.551 .099 .197 & $8,0 \%$ & 1.090 .389 .762 & $4,9 \%$ & $(460.709 .435)$ & $-42 \%$ \\
\hline & - Etc & 532.327 .782 & $2,8 \%$ & 316.494 .450 & $1,4 \%$ & $(215.833 .332)$ & $-41 \%$ \\
\hline & - Depreciation & 48.009 .497 & $0,2 \%$ & 55.802 .510 & $0,3 \%$ & 7.793 .013 & $0 \%$ \\
\hline & $-\operatorname{tax}$ & 281.945 .324 & $1,5 \%$ & 414.718 .471 & $1,9 \%$ & 132.773 .148 & $32 \%$ \\
\hline & -Admin & (139.196.026) & & $(25.217 .934)$ & $-0,1 \%$ & 113.978 .092 & $-452 \%$ \\
\hline & Net Profit & 821.798 .367 & $4,3 \%$ & 1.180 .981 .427 & $5,3 \%$ & 359.183 .060 & $30 \%$ \\
\hline
\end{tabular}

Source data: Actual Sales Data 2017 and 2018 
The above table 1.4 shows a drop of gross profit in the year $2018(13,9 \%)$ against gross profit of $3.6 \%$ versus $2017(17.5 \%)$. While the net profit increased due to salary and subsidy decreased by $3.1 \%$, the net profit increased by $1 \%$. This shows that the company's performance has not achieved maximum results.

Based on the above description, it shows how important the role of compensation factor, discipline, and motivation in increasing the performance of employees. This phenomenon prompted the writer to do research with the title: "the effect of compensation, discipline and motivation on the performance of employees of Mandiri Utama Sejahtera corporation on jombang bintaro,tangerang selatan.

\section{METHOD}

The research is a study of casual quantitative (because of the effect of processing data Numbers), using a method of survey by collecting data through distribution of questionnaires to central and branch employees, then The results were processed through the 23.00 version of the SPSS program. This research was held in the Mandiri Utama Sejahtera corporation where the address is at Bintaro Indah Villa, street Sulawesi 1, block F2/12A and the branches where exist in Bekasi, Tasik, Magelang, Nganjuk, and Madura. This research was done on March-August 2019. The population in this study is all of the subjects that were targeted. This population includes employees or 96 people of worker, which means the sample used in the study is an saturated sample The primary data in this study is the data that is obtained by direct research of employees of Mandiri Utama Sejahtera corporation With techniques of data-collection, observation and propagation of questionnaires. Secondary data was gained through literature review. This method of research analysis uses validity test, reliability test, linear regression test (simple and multiple), correlation test,determinative coefficient and significant test (test-t and test-f) and classic assumption test (normality test, multicollity test, heterosity test, autocorrelation).

\section{RESULT AND DISCUSSION}

Mandiri Utama Sejahtera Corporation is the national private corporation operating in the cargo services business ( Cargo Services ) especially in goods services of Personal Effects ( Moving Goods ) from Malaysia to Indonesia, Door to Door Service. The big vision of this corporation is to become a corporation in the sector of delivery services, transportation, and logistic that can provide the reliable rapid foremost business solution in quality and service. whereas the mission of the MUS corporation is : integrating the delivery, warehousing, rationing, and transport in one system which is integrated maximally, efficient and effective, and encouraging continued business growth in order to achieve the welfare of employees and always increasing social responsibility. 
104 Jurnal Ilmiah Ilmu Administrasi Publik: Jurnal Pemikiran dan Penelitian Administrasi Publik Volume 10 Number 1, January- june 2020. Page 99-112

\section{Validity and Reliability Test}

Based on the result of processed data by SPSS Version 23,00 is it follows: The result of processed data of $r_{\text {count }}$ on the $X_{1}$ variable (compensation) is 0,2988 0,7528, and $r_{\text {table }}$ is 0,2006. Every statement in the questionnaire shows that the value of $r_{\text {table }}$ is bigger than $r_{\text {count. }}(0,2988>$ 0,2006 ). The result of processed data of $r_{\text {count }}$ on the $X_{2}$ variable (discipline) is $0,21060,6724$, and $r_{\text {table }}$ is 0,2006. Every statement in the questionnaire shows that the value of $r_{\text {table }}$ is bigger than $r_{\text {count. }}(0,2988>0,2006)$. The result of processed data of $r_{\text {count }}$ on the $X_{3}$ variable (motivation) is $0,30220,5941$, and $r_{\text {table }}$ is 0,2006 . Every statement in the questionnaire shows that the value of $r_{\text {table }}$ is bigger than $r_{\text {count. }}(0,2988>0,2006)$. The result of processed data of $r_{\text {count }}$ on the $\mathrm{Y}$ variable (performance) is $0,32620,7609$, and $r_{\text {table }}$ is 0,2006 . Every statement in the questionnaire shows that the value of $r_{\text {table }}$ is bigger than $r_{\text {count. }}(0,2988>0,2006)$.

As for the reliable test results of all the variables in this research, it can be seen as the following table:

\section{Table 5.}

The Reliable Test Results of Variables

\begin{tabular}{clcccc}
\hline No & Variable & $\begin{array}{c}\text { Cronbach } \\
\text { Alpha }\end{array}$ & $\begin{array}{c}\text { The value of } \mathbf{r} \\
\text { table }\end{array}$ & Information & Criteria \\
\hline 1 & Compensation & 0,777 & 0,2006 & Reliable & High \\
2 & Discipline & 0,810 & 0,2006 & Reliable & High \\
3 & Motivation & 0,819 & 0,2006 & Reliable & High \\
4 & Performance & 0,924 & 0,2006 & Reliable & High \\
\hline
\end{tabular}

Resource : Primary processed data (2019)

\section{Classic Assumption Test}

The result of normality test can be seen in the table below:

\section{Table 6.}

The Results of Normality Test

One-Sample Kolmogorov-Smirnov Test

\begin{tabular}{lrr}
\hline & & Unstandardized Residual \\
\hline Normal Parameters ${ }^{\mathrm{a}, \mathrm{b}}$ & & 96 \\
& Mean &, 0000000 \\
Most Extreme Differences & Std. Deviation & 4,40706480 \\
& Absolute &, 080 \\
& Positive &, 080 \\
Test Statistic & Negative &,- 063 \\
Asymp. Sig. (2-tailed) & &, 080 \\
\hline a. Distribution test is Normal. & $.140^{c}$ \\
b. Calculated from the data. & & \\
c. Lilliefors Significance Correction. & & \\
Resource : The Result of 23-SPSS Processed Data &
\end{tabular}


From the results of testing above, it was acquired the following results if KolmogorovSmirnov $_{\text {count }}(0,080)<$ Kolmogorov-Smirnov table $(0,139)$, thus $\mathrm{H}_{0}$ is accepted (distributed data normally). The value of significance is $0,140>0,05$, thus it can be said that the distributed data is normal.

In this test of homogeneity, the researcher used the value of F Levene coefficient. If we use this measurement, the value of Levene coefficient should be compared with $\mathrm{F}_{\text {table }}$ critical value on the appropriate df 1 and df 2 and $\mathrm{H}_{0}$ is rejected if the coefficient of Levene $\geq \mathrm{F}_{\text {table }}$ critical value on the appropriate df 1 and df 2 .

\section{Table 7.}

\section{The Results of Homogenity Test}

Test of Homogeneity of Variances

\begin{tabular}{|c|c|c|c|c|}
\hline & Levene Statistic & df1 & df2 & Sig. \\
\hline Compensation & 1,154 & 17 & 71 &, 324 \\
\hline Discipline & 1,289 & 17 & 71 & ,225 \\
\hline Motivation & 1,357 & 17 & 71 &, 185 \\
\hline
\end{tabular}

a. Predictors: (Constant), Compensation, Discipline, Motivation

b. Dependent Variable: Performance

Resource : Primary processed data (2019)

Based on the result of analysis above, it can be shown that for the results of processed data from discipline, motivation, and performance show that each coefficient for Levene Statistics is ,154; 1,289; and 1,357 which is smaller than $F_{\text {table }}$ coefficient $(2,70)$, for df 1 is 17 and df 2 is 71 towards the $5 \%(0,05)$ of alpha and error rate, and each has a sig value as big as 0,$324 ; 0,225$; dan 0,185 which is bigger than 0,05 . Thus it can be claimed that the data is from a homogeneous population.

The results of heteroscedasticity test are indicated in the table below:

\section{Table 8.}

\section{The Results of Heteroscedasticity Test}

\section{Correlations}

\begin{tabular}{|c|c|c|c|c|c|c|}
\hline & & & Compensation & Discipline & Motivation & Abs_RES \\
\hline \multirow{8}{*}{$\begin{array}{l}\text { Spea } \\
\text { rman } \\
\text { 's rho }\end{array}$} & $\begin{array}{l}\text { Co } \\
\mathrm{mp}\end{array}$ & $\begin{array}{l}\text { Correlation } \\
\text { Coefficient }\end{array}$ & 1.000 & $.413^{* *}$ & $.406^{* *}$ & .197 \\
\hline & $\begin{array}{l}\text { ens } \\
\text { atio }\end{array}$ & $\begin{array}{l}\text { Sig. (2- } \\
\text { tailed) }\end{array}$ & . & . 000 & .000 & .054 \\
\hline & $\mathrm{n}$ & $\mathrm{N}$ & 96 & 96 & 96 & 96 \\
\hline & $\begin{array}{l}\text { Dis } \\
\text { cipl }\end{array}$ & $\begin{array}{l}\text { Correlation } \\
\text { Coefficient }\end{array}$ & $.413^{* *}$ & 1.000 & $.618^{* *}$ & $.330^{* *}$ \\
\hline & ine & $\begin{array}{l}\text { Sig. (2- } \\
\text { tailed) }\end{array}$ & .000 & . & .000 & .001 \\
\hline & & $\mathrm{N}$ & 96 & 96 & 96 & 96 \\
\hline & $\begin{array}{l}\text { Mot } \\
\text { ivat }\end{array}$ & $\begin{array}{l}\text { Correlation } \\
\text { Coefficient }\end{array}$ & $.406^{* *}$ & $.618^{* *}$ & 1.000 & $.217^{*}$ \\
\hline & ion & Sig. (2- & .000 & .000 & & .034 \\
\hline
\end{tabular}


106 Jurnal Ilmiah Ilmu Administrasi Publik: Jurnal Pemikiran dan Penelitian Administrasi Publik Volume 10 Number 1, January- june 2020. Page 99-112

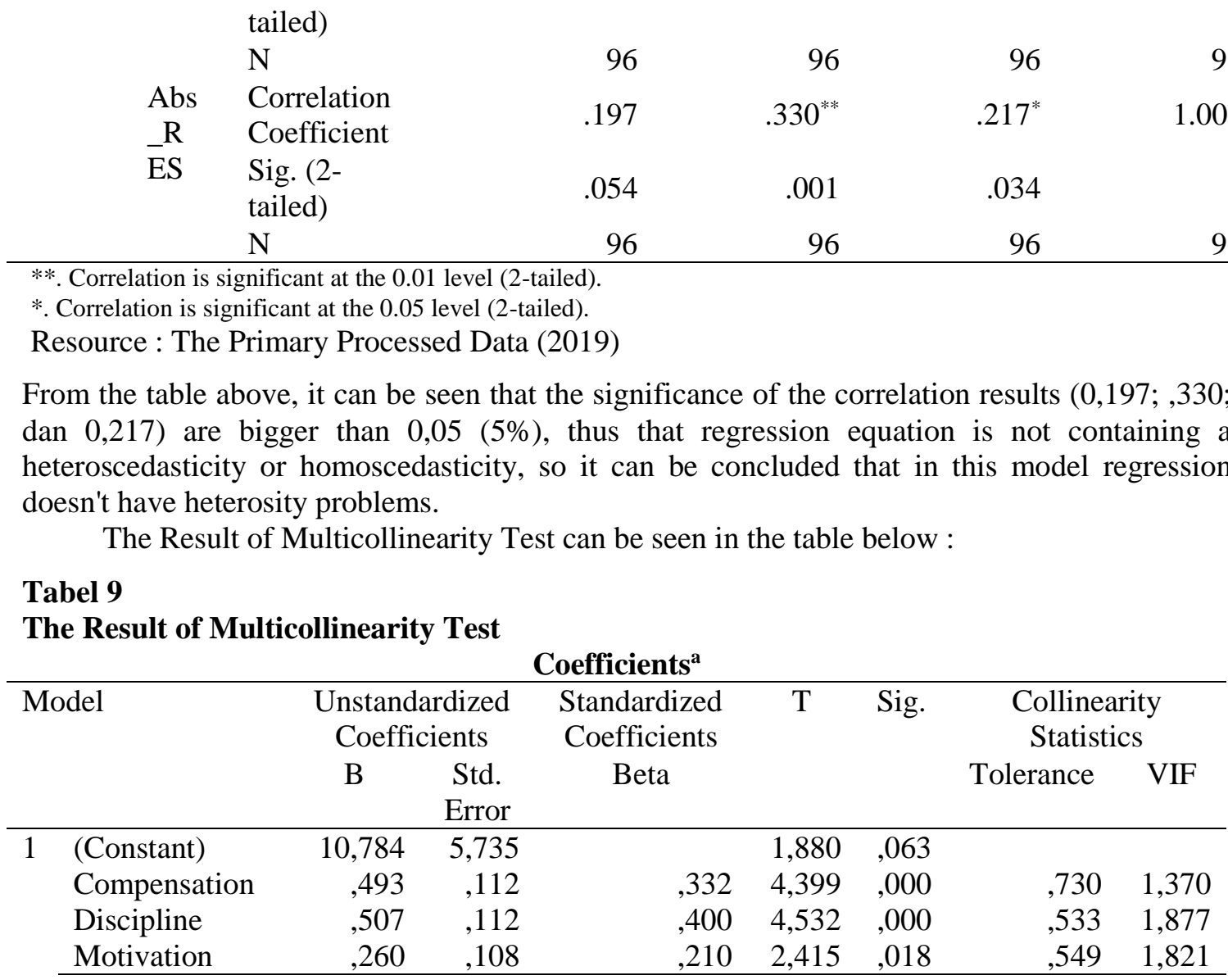

a. Dependent Variable: Performance

Resource : Primary Processes Data (2019)

From the data of the table above, it can be known that the requirements for passing from the multicollinearity test had been met by all the independent variables in existence, which is the value of tolerance is no less than 0,10 and VIF value (Variance Inflation Factor) no more than 10 , thus it can be concluded that all the independent variables used in this research are not correlated among independent variables one with other independent variables.

\section{The Test of $\mathbf{T}$ and $\mathrm{F}$}

The effect of compensational variable towards performance variable $\left(\mathrm{X}_{1}-\mathrm{Y}\right)$. The test of $\mathrm{T}$ on the motivational variable $\left(\mathrm{X}_{3}\right)$ is acquired that $\mathrm{t}_{\text {count }}$ is 7,729 with the significance of 0,000 . Because $t_{\text {count }}$ is bigger than $t_{\text {table }}(7,729>1,662)$ and the significance is smaller than $5 \%$ $(0,000<0,05)$, thus the motivational variable $\left(\mathrm{X}_{3}\right)$ partially has a positive and significant impact toward the employee performance variable $(\mathrm{Y})$. 
The effect of disciplinary variable towards performance variable $\left(\mathrm{X}_{2}-\mathrm{Y}\right)$. The test of $\mathrm{T}$ on the disciplinary variable $\left(X_{2}\right)$ is acquired that $t_{\text {count }}$ is 9,451 with the significance of 0,000 . Because $t_{\text {count }}$ is bigger than $t_{\text {table }}(9,451>1,66159)$ and the significance is smaller than $5 \%$ $(0,000<0,05)$, thus the disciplinary variable $\left(\mathrm{X}_{3}\right)$ partially has a positive and significant impact toward the employee performance variable $(\mathrm{Y})$.

The effect of motivational variable towards performance variable $\left(\mathrm{X}_{3}-\mathrm{Y}\right)$. The effect of compensation, discipline, and motivation toward the performance $\left(X_{1}, X_{2}, X_{3}-Y\right)$. From the result of the calculations, it is acquired that the value of $F_{\text {count }}$ is 49,460 with the significance of 0,000 . Thus $\mathrm{F}_{\text {count }}>\mathrm{F}_{\text {table }}(49,460>2,70)$ and the significance is smaller than $5 \%(0,000<$ 0,05). It means that the exempt variable which consists of Compensation $\left(\mathrm{X}_{1}\right)$, Disciplinary $\left(\mathrm{X}_{2}\right)$, and motivational $\left(\mathrm{X}_{3}\right)$ variable simultaneously has a positive and significant impact toward the employee performance variable (Y), like the table 4.18 above, which the value is 0,617 ( $R$ Square).

\section{The Test of Coefficient Correlation and Determination}

Based on the regression calculations using Software IBM SPSS (Statistical Program for Social Science) version 23.00 for windows, it is acquired the following result :

Table.10

The Result of Coefficient Determination $\left(X_{1}, X_{2}\right.$ and $X_{3}$ simultaneously toward $\left.Y\right)$.

\begin{tabular}{|c|c|c|c|c|}
\hline Model & $\mathrm{R}$ & R Square & $\begin{array}{l}\text { Adjusted R } \\
\text { Square }\end{array}$ & $\begin{array}{l}\text { Std. Error of the } \\
\text { Estimate }\end{array}$ \\
\hline 1 & $.786^{\mathrm{a}}$ & 617 & 605 & 4,478 \\
\hline
\end{tabular}

a. Predictors: (Constant), Compensation, Discipline, Motivation

Resource : Primary Processed Data (2019)

From the table 4.28, it can be seen that the value of strong $\mathrm{R}$ (correlation) is 0,786 and the value of $\mathrm{R}$ Square (determination) in that table above is 0,617 which shows that the $\mathrm{Y}$ variable (employee performance) is effected by the $\mathrm{X}_{1}$ (compensation), $\mathrm{X} 2$ (discipline) and $\mathrm{X}_{3}$ (motivation) variable simultaneously, which the value of that effect is $61,7 \%$ and the other of $38,30 \%$ is effected by other unresearched factors.

\section{Regression Test}

Based on the multiple regression calculations using Software IBM SPSS (Statistical Program for Social Science) version 23.00 for windows, it is acquired the following result table 11. 
108 Jurnal Ilmiah Ilmu Administrasi Publik: Jurnal Pemikiran dan Penelitian Administrasi Publik Volume 10 Number 1, January- june 2020. Page 99-112

Table 11

The Result of Multiple Regression Test

\begin{tabular}{llrr}
\multicolumn{4}{c}{ Coefficients $^{\mathbf{a}}$} \\
\hline Model & Unstandardized Coefficients \\
& B & 10,784 \\
\hline 1 & (Constant) &, 493 \\
& Compensation &, 507 \\
& Discipline &, 260 \\
\hline
\end{tabular}

a. Dependent Variable: Performance

Resource : Primary Processed Data (2019)

From the result of calculation in the table 4.32 above, it can be presented into the regression equation as follows: $\mathrm{Y}=10,784+0,493 \mathrm{X}_{1}+0,507 \mathrm{X}_{2}+0,260 \mathrm{X}_{3}$

The result of multiple regression equation can be seen that coefficient of regression which is gained is positive, it means that if the compensation, discipline, and motivation is increasing, thus the employee performance will increase

\section{CONCLUSION}

Based on the results of respondents' processed data about the variable of compensation, discipline, motivation and performance are as follow the Effect of Compensation towards The Employee Performance. Compensational variable (X1) partially has a strong, positive, and significant impact towards the performance variable $(Y)$ with the value of $t_{\text {count }}(7,710)>t_{\text {table }}$ $(1,66159)$ and the significance is smaller than $5 \%(0,000<0,05)$. It is acquired that the result of regression equation test is : $\mathrm{Y}=40,156+0,925 \mathrm{X} 1$. The value of $\mathrm{R}$ (correlation) is 0,622 and the value of $\mathrm{R}$ Square (determination) is 0,387. It shows that $\mathrm{Y}$ variable (employee performance) is effected by the $\mathrm{X} 1$ variable (compensation) which the value of that effect is $38,7 \%$ and the other of $61,30 \%$ is effected by other unresearched factors.

The Effect of Discipline towards Employee Performance. Disciplinary variable (X2) partially has a strong, positive, and significant impact towards the performance variable (Y) with the value of $t_{\text {count }}(9,451)>t_{\text {table }}(1,66159)$ and the significance is smaller than $5 \%$ $(0,000<0,05)$. It is acquired that the result of regression equation test is : $\mathrm{Y}=24,395+0,885$ $\mathrm{X} 2$. The value of $\mathrm{R}$ (correlation) is 0,698 and the value of $\mathrm{R}$ Square (determination) is 0,487 . It shows that $\mathrm{Y}$ variable (employee performance) is effected by the $\mathrm{X} 2$ variable (discipline) which the value of that effect is $48,70 \%$ and the other of $51,30 \%$ is effected by other unresearched factors.

The Effect of Motivation towards The Employee Performance. Motivational variable (X3) partially has a strong, positive, and significant impact towards the performance variable (Y) with the value of $t_{\text {count }}(7,729)>t_{\text {table }}(1,66159)$ and the significance is smaller than $5 \%$ $(0,000<0,05)$. It is acquired that the result of regression equation test is : $\mathrm{Y}=32,027+0,772$ $\mathrm{X} 3$. The value of $\mathrm{R}$ (correlation) is 0,623 and the value of $\mathrm{R}$ Square (determination) is 0,389 . It 
shows that $\mathrm{Y}$ variable (employee performance) is effected by the $\mathrm{X} 3$ variable (motivation) which the value of that effect is $38,90 \%$ and the other of $61,10 \%$ is effected by other unresearched factors.

The Effect of Compensation, Discipline, and Motivation toward Employee Performance In the simultaneous testing with using the $\mathrm{F}$ test shows that there is the highly significant impact of compensational (X1), disciplinary (X2), and motivational (X3) variable toward the performance variable $(Y)$. It can be proven by the value of $F_{\text {count }}(49,460)>F_{\text {table }}(2,70)$ and the significance is smaller than $5 \%(0,000<0,05)$. It is acquired that the result of the multiple regression equation test is: $\mathrm{Y}=10,784+0,493 \mathrm{X} 1+0,507 \mathrm{X} 2++0,260 \mathrm{X} 3$. Based on the result of $\mathrm{F}$ test simultaneously is acquired also the magnitude of growth effect of compensation, discipline, and motivation toward the employee performance. With the value of $\mathrm{R}$ (correlation) is 0,786 and the value of $\mathrm{R}$ Square (determination) is 0,617 . It shows that $\mathrm{Y}$ variable (employee performance) is effected by the $\mathrm{X} 1$ (compensation), $\mathrm{X} 2$ (discipline), and $\mathrm{X} 3$ (motivation) variable simultaneously, which the value of that effect is $61,70 \%$ and the other of $38,30 \%$ is effected by other unresearched factors..

\section{REFERENCES}

Bebchuk, L. A., \& Fried, J. M. (2012). Executive compensation as an agency problem. In The Economic Nature of the Firm: A Reader, Third Edition. https://doi.org/10.1017/CBO9780511817410.026

Bircan, İ., \& Gençler, F. (2015). Analysis of Innovation-Based Human Resources for Sustainable Development. Procedia - Social and Behavioral Sciences, 195, 1348-1354. https://doi.org/https://doi.org/10.1016/j.sbspro.2015.06.321

Brown, S., Gray, D., McHardy, J., \& Taylor, K. (2015). Employee trust and workplace performance. Journal of Economic Behavior \& Organization, 116, 361-378. https://doi.org/https://doi.org/10.1016/j.jebo.2015.05.001

Core, J. E., Holthausen, R. W., \& Larcker, D. F. (1999). Corporate governance, chief executive officer compensation, and firm performance. Journal of Financial Economics. https://doi.org/10.1016/S0304-405X(98)00058-0

Doyle, S. (2019). Section 6 - Discipline-Specific Quality Management (S. B. T.-Q. M. in F. S. Doyle (ed.); pp. 245-323). Academic Press. https://doi.org/https://doi.org/10.1016/B9780-12-805416-1.00006-2

Freitas, V., \& Duarte, M. (2017). Motivation at work: Case studies of Portuguese SMEs. Tékhne, 15(2), 88-99. https://doi.org/https://doi.org/10.1016/j.tekhne.2017.11.002

Gerhart, B. (2008). Compensation. In The Routledge Companion to Strategic Human Resource Management. https://doi.org/10.4324/9780203889015-25

Kim, H. S., \& Jang, S. (Shawn). (2020). The effect of increasing employee compensation on firm performance: Evidence from the restaurant industry. International Journal of Hospitality Management, 88, https://doi.org/https://doi.org/10.1016/j.ijhm.2020.102513 
110| Jurnal Ilmiah Ilmu Administrasi Publik: Jurnal Pemikiran dan Penelitian Administrasi Publik Volume 10 Number 1, January- june 2020. Page 99-112

Kusuma, I., \& Ardana, K. (2014). Pengaruh Penempatan dan Kompensasi Terhadap Kepuasan Kerja dan Kinerja Karyawan. E-Jurnal Manajemen Universitas Udayana.

Levine, D. K., \& Modica, S. (2016). Peer discipline and incentives within groups. Journal of Economic Behavior \& Organization, 123, 19-30. https://doi.org/https://doi.org/10.1016/j.jebo.2015.12.006

Nicolau, C., \& Foris, T. (2018). Human Resources Crisis: Identifying Future Entrepreneur's Profile in Romania. Procedia - Social and Behavioral Sciences, 238, 572-581. https://doi.org/https://doi.org/10.1016/j.sbspro.2018.04.037

Niswaty, R., Rusbiati, S., Jamaluddin, J., \& Salam, R. (2017). The Influence of Teacher's Reinforcement for Students Motivation. International Conference on Education, Science, Art and Technology, 148-152.

Saggaf, M. S., Nasriyah, N., Salam, R., \& Wirawan, H. (2018). The Influence of Teacher's Pedagogic Competence on Learning Motivation of Student of Office Administration Expertise Package.

Sastrohadiwiryo. (2010). Manajemen Tenaga Kerja Indonesia Pendekatan Administrative dan Operasional. Bumi Aksara.

Sujatha, R., \& Krishnaveni, R. (2018). Knowledge creating ba as a determinant of work performance of employees: An empirical analysis among pump manufacturing firms in South India. Asia Pacific Management Review, 23(1), 45-52. https://doi.org/https://doi.org/10.1016/j.apmrv.2017.01.006

Sunarsi, D. (2014). Pengaruh Gaya Kepemimpinan, Disiplin dan Motivasi Terhadap Kinerja. Tesis. Fakultas Ekonomi Universitas Pamulang.

Sunarsi, D. (2018a). Pengaruh Gaya Kepemimpinan, Motivasi Dan Disiplin Kerja Terhadap Kinerja Pendidik Yayasan Marvin. Inovasi, 5(1), 1-18.

Sunarsi, D. (2018b). Pengaruh Gaya Kepemimpinan dan Disiplin Kerja Terhadap Kinerja Karyawan Pada CV. Usaha Mandiri Jakarta. JENIUS, 1(2).

Sunarsi, D., \& Yuliani, I. (2019). Pengaruh Gaya Kepe Mimpinan Dan Budaya Organisasi Terhadap Kinerja Karyawan Pada Bank BTN KANTOR CABANG TANGERANG. Jurnal Semarak, 2(1).

Vardarlier, P. (2016). Strategic Approach to Human Resources Management During Crisis. Procedia - Social and Behavioral Sciences, 235, 463-472. https://doi.org/https://doi.org/10.1016/j.sbspro.2016.11.057

Waris, A. P. M. dan A. (2015). Effect of Training, Competence and Discipline on Employee Performance in Company (Case Study in PT. Asuransi Bangun Askrida). Procedia Social and Behavioral Sciences. https://doi.org/10.1016/j.sbspro.2015.11.165 
Rahmi Hermawati; Analysis on The Effect of Compensation, Discipline ...| 111 